\title{
チタン合金の水素誘起割れ
}

\author{
野末 章 遠藤 剛 司什 \\ 立石 征爾十 大久保忠恒
}

\author{
上智大学理工学部機械工学科
}

J. Japan Inst. Metals, Vol. 62, No. 4 (1998), pp. 358-362

\section{Hydrogen-Induced Cracking in Titanium Alloys}

\author{
Akira Nozue, Koji Endo"t, \\ Seiji Tateishi ${ }^{\dagger \dagger}$ and Tadatsune Okubo
}

Department of Mechanical Engineering, Faculty of Science and Technology, Sophia University, Tokyo 102-8554

\begin{abstract}
It has been suggested that hydrogen-induced cracking may occur in titanium alloys utilized in aggressive environments. In the present study, hydrogen-induced cracking in conventionally heat-treated titanium alloys was evaluated on the basis of microstructure and stress conditions. Ti-15V-3Cr-3Sn-3Al, Ti-10V-2Fe-3Al and Ti$6 \mathrm{Al}-4 \mathrm{~V}$ alloys with fatigue pre-cracks were tested in the compact tension specimen whilst undergoing cathodecharging in a $\mathrm{H}_{2} \mathrm{SO}_{4}$ solution at $200-1000 \mathrm{~A} / \mathrm{m}^{2}$ in order to simulate an aggressive operating environment. Crack initiation and propagation were characterized by using acoustic emission, crack opening displacement and video microscopy. Under no-loading conditions, the Ti-15V-3Cr-3Sn-3Al and Ti-10V-2Fe-3Al alloys failed during cathode charging, whilst the Ti-6Al-4V alloy was uncracked. These differences are attributed to the very fine precipitation $\alpha$ in a matrix of $\beta$ for the Ti-15V-3Cr-3Sn-3Al and Ti-10V-2Fe-3Al alloys, which may promote hydrogen-induced cracking. Acoustic emission and the crack opening displacement rapidly increased at a position close to the corresponding threshold stress intensity factor estimated in a previous study of delayed cracking by the authors.
\end{abstract}

(Received November 6, 1997; In Final Form January 6, 1998)

Keywords: hydrogen-induced cracking, titanium alloy, microstructure, acoustic emission, crack opening displacement

\section{I. 緒言}

チタン合金は力学特性に加え耐食性にる優れて和り, 海用 構造物, 燃料タンク等のような浸食性環境下の構造物として 使用されている(1). 今後, 過酷な浸食性環境での使用が考克 られる. 硫化水素環境下のラインパイプ鋼では, 外力の存在 なしに破壊を起こしている(2)。この水素誘起割れでは, 介在 物等の界面に分子状の水素が集積し，荷重を生じ，破壊に至 るとされている(3).チタン合金に和いても，過酷な浸食性環 境下で，水素誘起割れの可能性がある，そこで本研究では， 過酷な浸食性環境のモデル環境として, 陰極電解時に大きな 電流密度を設定し，母相が鋼と同様に BCC 構造を呈する代 表的な $\beta$ 型チタン合金である Ti-15V-3Cr-3Sn-3Al 合金(以 下15-3 合金と略記する)を主たる供試材とし, 起こりらる水 素誘起割れを組織と力学的観点から明らかにする.

† 1997年9月日本金属学会秋期大会に拈いて発表 †十 上智大学大学院生 (Graduated Student, Sophia University)

\section{II. 方法}

\section{1. 供試材と熱処理}

ASTM 規格 E399-90(4) 飞準趐した板厚 $4 \mathrm{~mm}$, 初期き裂 長さ $12 \mathrm{~mm}$ (疲労予き裂約 $2 \mathrm{~mm}$ を含む), 板幅 $28 \mathrm{~mm}$ の CT 試験片に所定の熱処理を行い，その表面を鏡面研磨し， 陰極電解を施した。

(1) 15-3 合金

15-3 合金を本研究の主たる材料とした。その組成はV: $14.9 \%, \mathrm{Cr}: 2.89 \%, \mathrm{Sn}: 2.90 \%, \mathrm{Al}: 3.14 \%, \mathrm{Fe}: 0.21 \%, \mathrm{O}$ : $0.122 \%, \mathrm{H}: 0.013 \%, \mathrm{C}: 0.011 \%, \mathrm{~N}: 0.0094 \%$, Ti :残であ る. 単位は mass\%であり，他の合金も同様の単位である。 $1223 \mathrm{~K}, 3.6 \mathrm{ks}$ の溶体化処理後, $783 \mathrm{~K}, 50.4 \mathrm{ks}$ のピーク時 効処理と $783 \mathrm{~K}, 14.4 \mathrm{ks}$ の两時効処理(5)を行った。 その組 織をFig. 1 (a)に示す.

\section{(2) Ti-10V-2Fe-3Al 合金}

準 $\beta$ 型チタン合金として, Ti-10V-2Fe-3Al 合金(以下102-3 合金と略記する) 学15-3 合金の比較材として使用した。 その組成は V : 10.4\%, Fe : 2.09\%, $\mathrm{Al}: 3.25 \%, \mathrm{O}: 0.110 \%$ ， 
$\mathrm{H}: 0.0073 \%, \mathrm{C}: 0.007 \%, \mathrm{~N}: 0.007 \%, \mathrm{Ti}:$ 残である. 本合 金の標準的熱処理 (6)である $1013 \mathrm{~K}, 3.6 \mathrm{ks}$ の溶体化処理之 $783 \mathrm{~K}, 28.8 \mathrm{ks}$ の時効処理を施した。その組織を Fig. 1(b) に示す。

\section{(3) Ti-6Al-4V 合金}

代表的 $\alpha+\beta$ 型子タン合金として，Ti-6Al-4V 合金（以下 6-4 合金と略記する)を15-3 合金の比較材として使用した。 その組成は $\mathrm{Al}: 6.46 \%, \mathrm{~V}: 4.28 \%, \mathrm{Fe}: 0.290 \%, \mathrm{O}: 0.193 \%$, $\mathrm{H}: 0.003 \%, \mathrm{C}: 0.004 \%, \mathrm{~N}: 0.008 \%, \mathrm{Ti}:$ 残である. 水素の 供給路としての $\beta$ 相の量を制御するため，比較的多量の $\beta$ 相を残存させる熱処理である $1023 \mathrm{~K}, 3.6 \mathrm{ks}$ 保持後空冷の $\alpha$

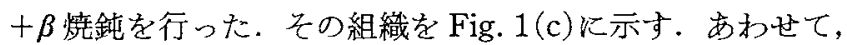
$1228 \mathrm{~K}, 5.4 \mathrm{ks}$ の溶体化処理, $813 \mathrm{~K}, 21.6 \mathrm{ks}$ の時效処理も 行った。

\section{2. 陰極電解法}

$303 \mathrm{~K}$ の0.1規定硫酸水溶液内に CT 試験片を浸漬し，白 金板を刘極として，無負荷状態で陰極電解を破断まで継続し

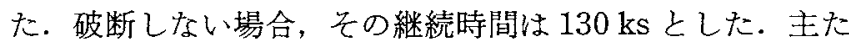
る電流密度は $600 \mathrm{~A} / \mathrm{m}^{2}$ である。

\section{3. 水素吸蔵による荷重発生と割れのモニター}

陰極電解中, き裂開口変位 $(\mathrm{COD})$ と $\mathrm{AE} の$ 測定,ならび にビデオマイクロスコープによるき裂進展の観察を以下の方 法で行った。

(1) COD の測定

MTS 社製の CT 試験片用クリップゲージを用い，COD を測定した。

\section{(2) $\mathrm{AE}$ 事象数の測定}

ステンレス鋼で保護された $170 \mathrm{kHz}$ 共振型 $\mathrm{AE}$ 変換子(7) を, 水溶液内の疲学予き裂先端近傍に 1 個装着し， $\mathrm{AE}$ 事象 数を測定した。全利得は $60 \mathrm{~dB}$ である.

\section{（3）表面のき裂進展の観察}

疲労予き裂先端表面のき裂進展をビデオマイクロスコープ により観察した。

\section{III. 結果}

\section{1. 気泡発生による AE の測定としきい值の設定}

き裂進展のモ二ターとして， $\mathrm{AE}$ 法は有力な手法であ る(8). しかし，陰極電解時には，気泡発生による大きな環境 雑音が存在する(9)。そこで，CT試験片と同じ板厚，同じ表 面状態の15-3 合金を使用し，気泡発生による $\mathrm{AE}$ を $3.6 \mathrm{ks}$ 間測定した. Fig. 2 のようた，大きな振幅の AE が存在し，

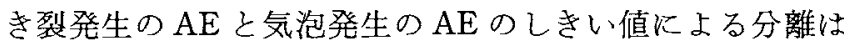
困難である.Fig. 2 の横軸は $\mathrm{AE}$ 变換子の出力換算の值であ る. 環境雑音を大幅に除去し，かつき裂発生のモ二タ一可能 なしきい值として，1.4 mVに設定した。ただし，1.4 mV 以上の $\mathrm{AE}$ は $3.6 \mathrm{ks}$ 間に約 40 個測定された。

2. 陰極電解中の $\mathrm{COD}$ と $\mathrm{AE}$ の測定とビデオマイクロス コープによるき裂進展の観察

ピーク時効処理した15-3 合金の CT 試験片を用いて，600

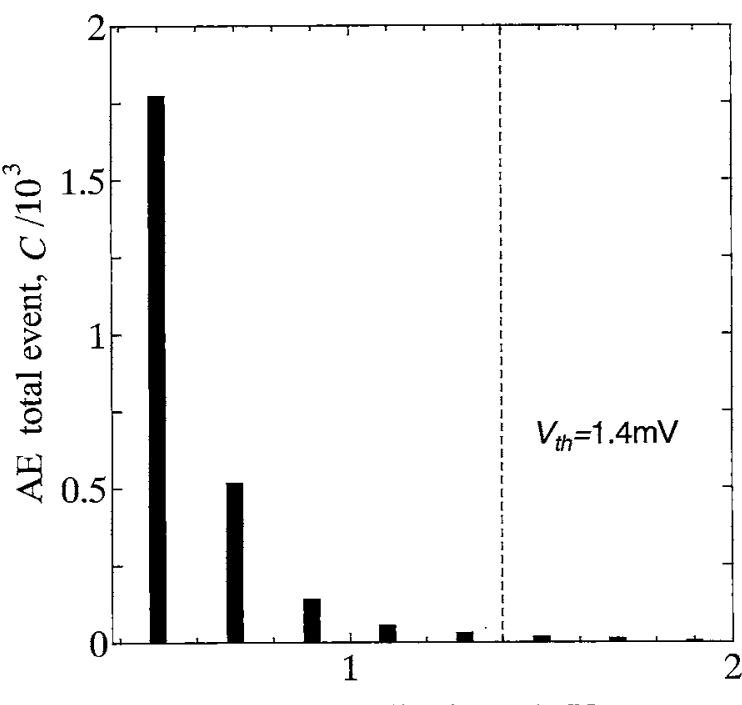

Amplitude, $V / \mathrm{mV}$

Fig. 2 AE peak amplitude of Ti-15V-3Cr-3Sn-3Al alloy during cathode-charging for $3.6 \mathrm{ks}$.

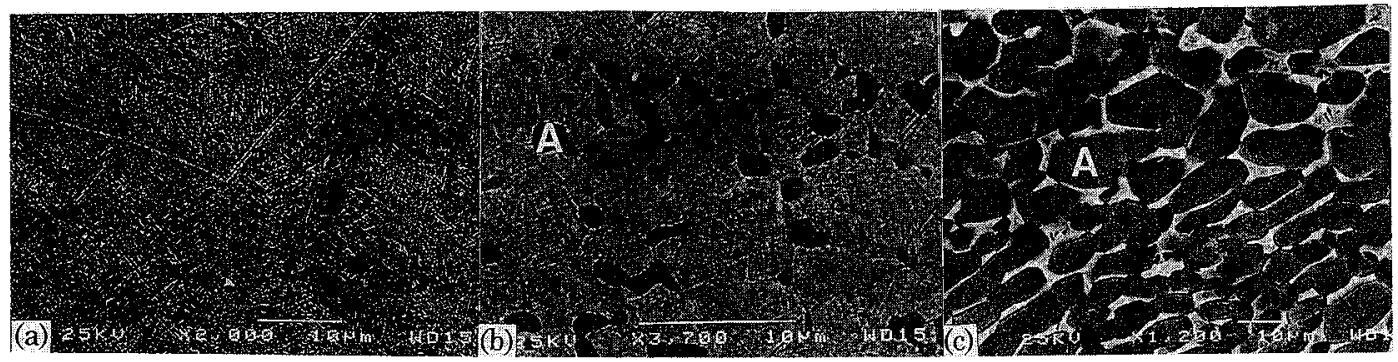

Fig. 1 Microstructures of (a) Ti-15V-3Cr-3Sn-3Al, (b) Ti-10V-2Fe-3Al and (c) Ti-6Al-4V alloys after conventional heat-treatment. Marked A shows $\alpha$ phase. 
$\mathrm{A} / \mathrm{m}^{2}$ の電流密度で陰極電解を施し，CODとAEの测定を 行らと同時に，ビデオマイクロスコープにより疲労予き裂先 端の表面部のき裂進展を観察した．Fig. 3 に示されるよう に, 水素吸蔵後, $\mathrm{AE}$ 事象数は直旉増し, $\mathrm{COD}$ は約 $900 \mathrm{~s}$ 後に増加し始めた。この上らな COD 点 $\mathrm{a} て ゙ \mathrm{AE}$ が急増し，少し遅れて点 $\mathrm{b} て ゙ \mathrm{COD}$ が急増し， Videoで表示されている点で表面部のき裂進展がビデオマイ クロスコープにより観察された。

\section{3. 破面観察}

Fig. 3 で使用した試験片の破面を走查電子顕锺鏡で観察し た.Fig. 4 に見られるよら飞、リバーパターンを呈するへ き開割れが観察された。き裂進展方向は下から上である。

\section{4. 電流密度の影響}

本研究の標準的な電流密度に加光, $200 \mathrm{~A} / \mathrm{m}^{2}, 400 \mathrm{~A} / \mathrm{m}^{2}$,

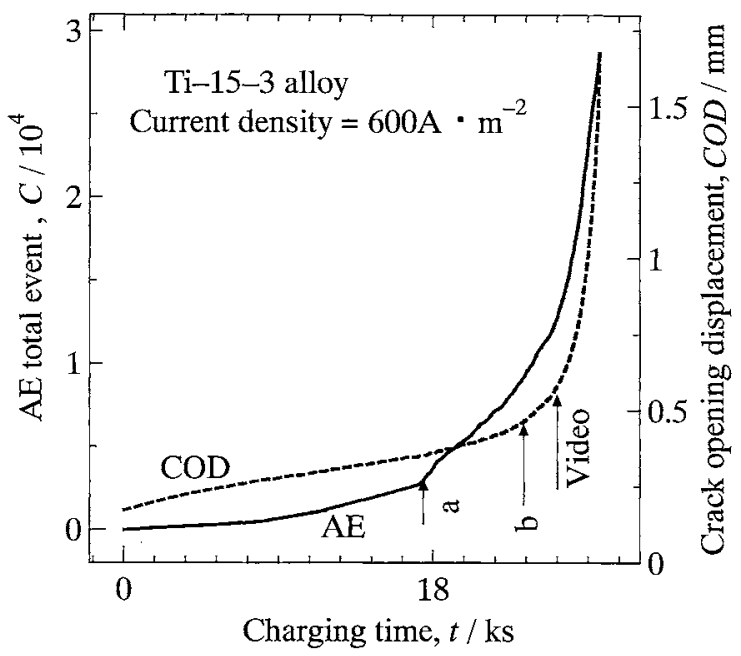

Fig. 3 AE total event and crack opening displacement (COD) vs. charging time with $\mathrm{CT}$ specimen of Ti-15V-3Cr-3Sn-3Al alloy during cathode-charging.

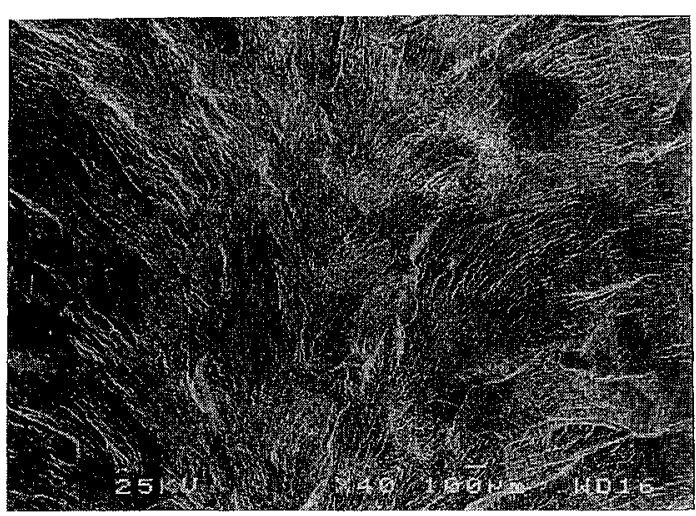

Fig. 4 Fracture surface of Ti-15V-3Cr-3Sn-3Al alloy peakaged after cathode-charging. Crack propagation direction is from lower to upper.
$1000 \mathrm{~A} / \mathrm{m}^{2}$ の条件の実験を行った．Fig.5に示されるよら に，電流密度の増加に伴い，破断時間は減少した。

\section{5. 組織の影響}

各組織の水素誘起割れに与学る影響を明らかとするため， 15-3 合金のピーク時効材以加え， 15-3 合金の亜時効材，102-3 合金，6-4 合金を用いて，600 A/m² の条件で陰極電解を 行った．Fig. 6 に示されるように，15-3 合金のピーク時効 材が最多速く破断した。6-4合金以おいては，本実験の測定 時間内で，荷重の発生が殆んどなく，き裂の発生も生じなか

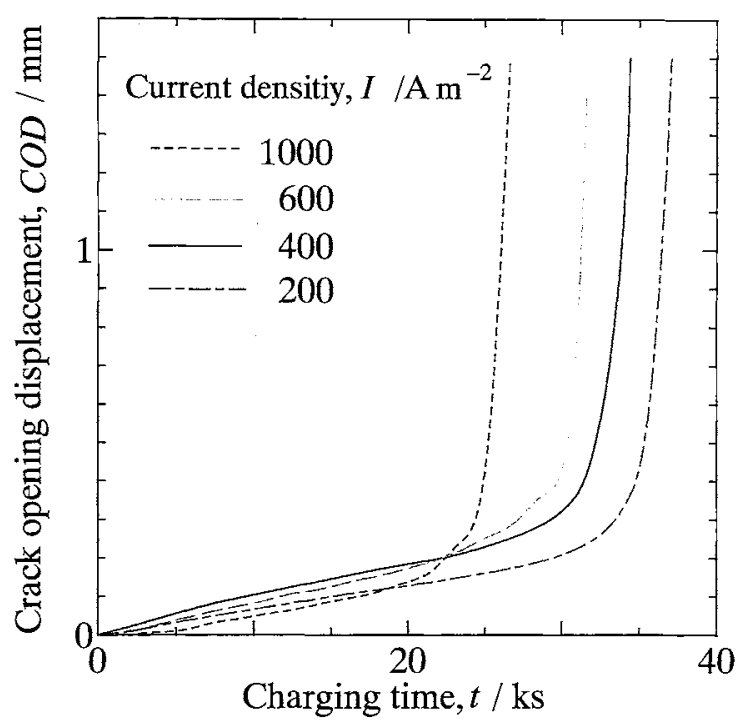

Fig. 5 Effect of current density on COD in Ti-15V-3Cr-3Sn$3 \mathrm{Al}$ alloy.

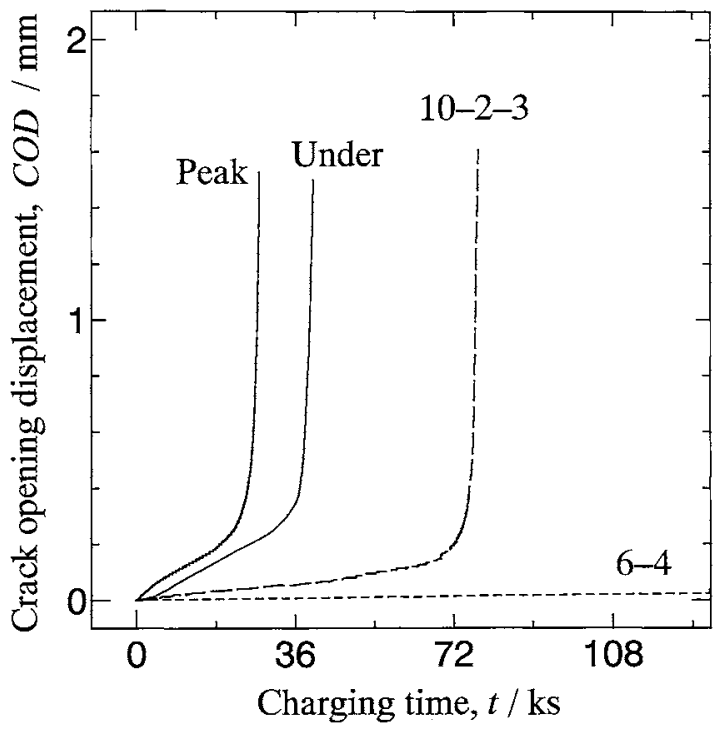

Fig. 6 COD vs. charging time for four types of material. The symbols of Peak, Under, 10-2-3, 6-4 designate Ti-15V-3Cr3Sn-3Al alloys peak-aged and under-aged, Ti-10V-2Fe-3A1 alloy, and $\mathrm{Ti}-6 \mathrm{Al}-4 \mathrm{~V}$ alloy, respectively. 


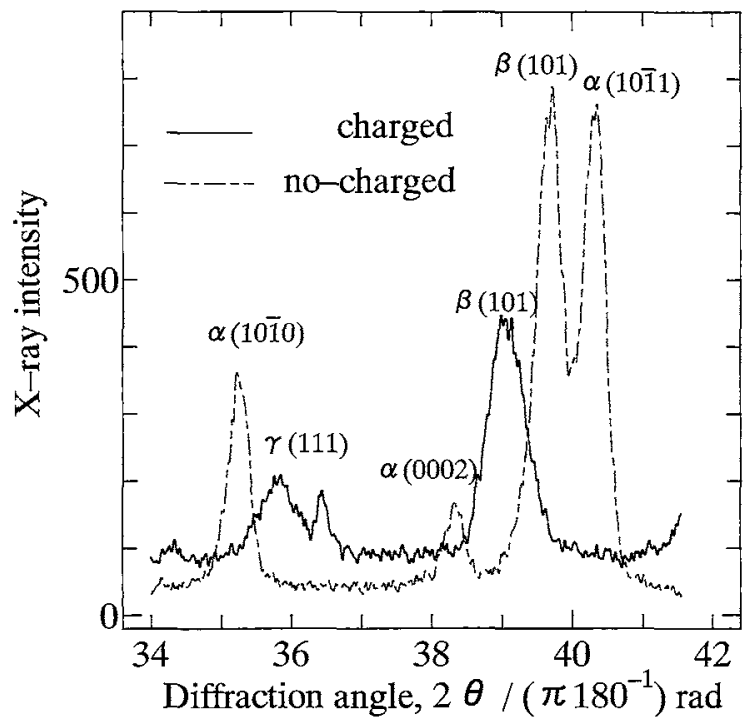

Fig. 7 X-ray diffraction of Ti-15V-3Cr-3Sn-3Al alloys cathode-charged and no charged.

った。な拈，6-4 合金の $\alpha+\beta$ 焼鈍材之溶体化-時效処理材で は, $\mathrm{COD}$ の時間に対する変化飞顕著な有意差はなく,一つ の曲線として描いた。

\section{X線回折}

15-3 合金のピーク時効材について，水素吸藏前後の X 線 回折結果をFig. 7 亿示す. 水素吸蔵後, $\alpha$ 相のピークが消 失し，办素化物である $\gamma$ 相のピークが出現し， $\beta$ 相のピーク が低角側に移動している。

\section{N. 考察}

\section{1. 水素の吸蔵により発生する内部荷重の推定}

Fig. 3 亿括いて，AE 事象数の点 $\mathrm{a}$ までの線形的な増加は 陰極電解時の気泡発生に基づく, 点 $\mathrm{a}$ 以降の急增恃気泡発 生に加えてき裂発生が大きく寄与していると思われる。 $\mathrm{COD}$ に関し，点bまでの漸増は，主き裂進展によるコンプ ライアンスの増加ではなく，水素の吸藏炕上る荷重発生とそ

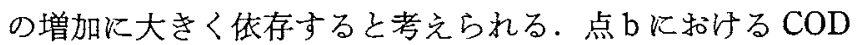
の急堌は主き裂の進展迆ると理解される.

15-3 合金のピーク時效枋のCT 試験片について，COD上 り荷重を推定する。裂を疲労により進展させ, 既知の荷重 に対するCOD を測定し，Fig. 8 のような較正曲線を作成し た.データを最適化し，式（1）の級数解で近似した。

$$
\frac{\mathrm{COD}}{\mathrm{load}}=\sum C_{i} a^{i}
$$

ここで, $C_{0}=-1.42 \times 10^{-2}, C_{1}=5.94 \times 10^{-3}, C_{2}=-1.01 \times$ $10^{-4}, C_{3}=8.95 \times 10^{-5}, C_{4}=-4.35 \times 10^{-6}, C_{5}=1.09 \times 10^{-7}$, $\mathrm{C}_{6}=-1.10 \times 10^{-9}$ である。

Fig. 3 の点b末で, 主き裂の進展はなく, COD の漸増が
荷重の発生々その上昇に基づくものと仮定し, 荷重を式 （1）上り推定した。Fig. 9 のように, 荷重は約 $22 \mathrm{ks}$ 索で

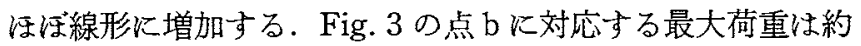
$2 \mathrm{kN}$ である.この最大荷重と初期き裂長さより，応力拡大 俰数 $\mathrm{K}$ は約 $24 \mathrm{MPa} \sqrt{\mathrm{m}}$ と計算される。この值は本合金の 破壊勒性 $35 \mathrm{MPa} \sqrt{\mathrm{m}}$ の約 $68 \%$ である.チタン合金の連れ破 壊の下限界応力拡大係数と破壊勒性の比は約 $64 \%$ であるこ 之が得られて打り ${ }^{(10)}$ ，水素誘起割れと水素脆性は必ずしも 同じ挙動ではないが，Fig. 3 の点 b は下限界応力拡大係数に 近い値之思われる.

\section{2. 水素誘起割れ挙動}

Fig. 5 で示される上うに, 本研究で設定した陰極電解の電 流密度梳非常に大きく，試験片内に過剩な水素が供給されて いる. 本研究では, 15-3合金と10-2-3 合金に执いて, ライン パイプ鋼とほぼ同様な水素誘起割れが観察された。一般的

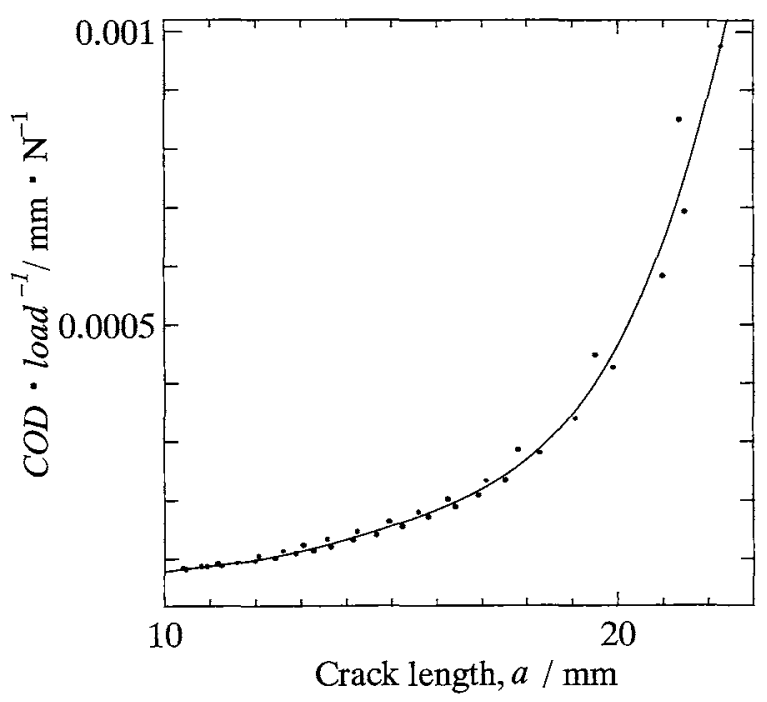

Fig. 8 Relation $\mathrm{COD} /$ load and crack length for $\mathrm{CT}$ specimen of Ti-15V-3Cr-3Sn-3Al alloy.

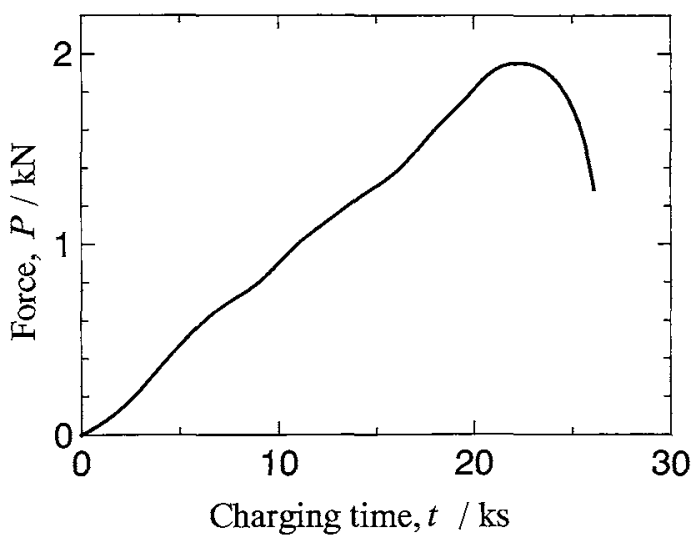

Fig. 9 Force estimated by COD in Ti-15V-3Cr-3Sn-3Al alloy. 
に, チタンは水素に対して発熱反応であるのに対し，鉄は吸 熱反応であり(11), 本合金とラインパイプ銅の水素誘起割れ を同一のメカニズムで必ずしも議論することはできないが， へき開割れの破壊形態, 水素供給量の破断時間への依存性, $\mathrm{BCC}$ 結晶構造の存在，第二相の存在等の類似点は多い。

Fig. 7 の水素吸蔵後のX 線回折から， $\alpha$ 相ピークの消失 と $\gamma$ 相ピークの出現より， $\alpha$ 相中に括ける水素化物の形成, ならびに $\beta$ 相ピークの低角側の移動とその半価幅の堌加よ り， $\beta$ 相中に招ける多量の水素の固溶が理解できる. 水素の 存在について, 現在, 可視化の有力な手法である $\operatorname{SIMS}^{(12)}$ を用いて，15-3 合金の観察を試みたが，多量な水素の存在 と微細な析出 $\alpha$ 相のため，明瞭な識別はでさなかった．Fig. 6 で示されるように，水素誘起割れが15-3 合金で非常に短時 間に起き，10-2-3 合金でも生じ，6-4 合金で殆んど生じなか ったことは，微細な析出 $\alpha$ 相と $\beta$ 相の存在が水素誘起割れ に大きく奇与していると思われる。

周知のよ5飞， $\beta$ 相に扣ける水素の搪散俰数は $\alpha$ 相上り非 常に高く(13)，水素の固溶量の少ない $\alpha$ 相で水素化物を形成 する(14). 本合金の水素誘起割れ過程としては, 水素が $\mathrm{BCC}$ 構造である母相の $\beta$ 相を主に拡散し, HCP 構造である析出 $\alpha$ 相に颃いて, 水素化物を形成し，ほ房すべての析出 $\alpha$ 相が 水素化物に変化する. ポテンシャルエネルギーの高い析出 $\alpha$ 相と $\beta$ 相の界面に水素が過剩に集積し, 試験片内部に引張 荷重を生じ，疲労予き裂により応力集中をむたらす。その 後, 水素化物の破壊を起点とし, 最終破断任至ると推測され る.しかし, 試験片に引張荷重が生しる詳細な機構は不明で ある. $\alpha$ 相の水素化物への変化に上る荷重発生の可能性はあ るが，その体積変化は10 20\%程度(1)と少なく，発生する 荷重は主に圧縮(14)であり，Fig. 6 で示されるように $\alpha$ 相が 多い6-4 合金では水素誘起割れが殆ど観察されていないこと から，その可能性は低い，水素々は発熱反応と考えられる本 合金衹打いて，分子状の水素に上る内部荷重の発生の可能性 については, 水素の存在状態の解明が必要であり，水素分析 の今後の進展を期待したい.いずれにしても，過㮃な水素供 給と相俟って, 水素の補給路として必要な比較的多量の $\beta$ 相の存在,ならびに水素化物の形成と水素集積に必要な多く
の界面をるたらす析出 $\alpha$ 相の存在により，水素諉起割れが 発生すると理解できる。

\section{V. 結 論}

Ti-15V-3Cr-3Sn-3Al 合金之 Ti-10V-2Fe-3Al 合金の $\beta$ 型于 タン合金に扣いて，水素の過剩供給により発生した水素誘起 割れについて，組織と力学的観点から検討し，以下のことを 明らかにした。

（1）過剰な水素供給，水素の補給路として比較的多量の $\beta$ 相の存在，ならびに水素化物の形成と水素集積となりらる多 くの界面を有する微細な析出 $\alpha$ 相の存在以上り，水素誘起 割れが発生した。

（2）水素吸蔵で生じた最大荷重は遅れ破壊の下限界応力拡 大係数に㾏注対底し，その応力状態で水素誘起割れが発生し た。

\section{文献}

(1) M. J. Blackburn, J. A. Feeney and T. R. Beck: Advances in Corrosion Science and Technology, Ed. by M. G. Fontana and R. W. Staehle, Plenum Press, 3(1973), 67.

(2) R. W. Revie, V. S. Sastri, G. R. Hoey, R. R. Ramsingh, D. K. Mak and M. T. Shehata: Corrosion, 49(1993), 17.

（3）寺崎副久長：日本金属学会会報, 16(1977), 789 .

(4) Annual book of ASTM Standards, Vol. 03. 01, ASTM E399-90, p. 485.

（5）野末 章, 坂巻兵衛, 斎田洋二, 大久保忠恒: 日本金属学会 誌, $\mathbf{5 7}$ (1993), 1136.

(6) Metals Handbook Ninth Edition, ASM, 2(1979), 395.

(7) 野末 章, 岸 㟕雄, 淈内 良: 鉄と鋼, 67(1981), 1787.

(8) A. Nozue, T. Okubo and A. Sano: Corrosion Engineering, $44(1995), 345$.

（9）湯山茂徳，久松敬弘，岸 輝雄：日本金属学会誌，46(1982), 85.

（10）野末 章：鉄鋼の高強度化の最前線，日本鉄鋼協会，(1995）, 173.

(11) O. M. Katz and J. A. Berger: Trans. Met. Soc. AIME, 233(1965), 1005.

(12) 高井健一：材料試験技術， 40 (1995)，15.

(13) T. P. Perng and C. J. Altstetter: Met. Trans., 17A(1986), 2086.

（14）野末 章, 春日憲治, 渡辺知夫, 大久保忠恒：日本金属学会 誌, $\mathbf{5 6}(1992), 735$. 